\title{
Evaluation of polymeric PLGA nanoparticles conjugated to curcumin for use in aPDT
}

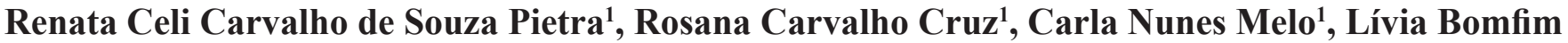 \\ Rodrigues $^{2}$, Patrícia Campi Santos ${ }^{3}$, Gabriel Pissolati Matos Bretz ${ }^{3}$, Betânia Maria Soares ${ }^{1}$, Gerdal \\ Roberto de Sousa ${ }^{1}$, Marcus Vinícius Lucas Ferreira ${ }^{1 *}$, Patrícia Silva Cisalpino ${ }^{3}$, Paula Prazeres \\ Magalhães $^{3}$, Luiz de Macêdo Farias ${ }^{3}$, Marcos Pinotti ${ }^{1}$
}

${ }^{1}$ Bioengineering Laboratory, Department of Mech. Eng., Universidade Federal de Minas Gerais (UFMG), Brazil, ${ }^{2}$ Department of Pharmaceutical Products, UFMG, Brazil, ${ }^{3}$ Department of Microbiology, Institute of Biological Sciences, UFMG, Brazil

\begin{abstract}
Antimicrobial photodynamic therapy (aPDT) involves the association of a photosensitizing agent with a light source with the goal of causing apoptosis or microbial lysing. The use of compounds with natural active principles is gaining prominence throughout the world. Several studies from groups that are linked to the development of innovations in the pharmaceutical market have used natural dyes, such as curcumin, the efficacy of which has been demonstrated in aPDT trials. Difficulties related to physicochemical stability, solubility and cell penetration are some of the challenges associated with this field. The present work aimed to prepare, investigate the characteristics and improve the photodynamic activity of PLGA-based nanoparticles loaded with curcumin for use in aPDT therapy. Using the simple technique of emulsion during the evaporation of a solvent, the particles were built, characterized and tested against microorganisms with importance for medicine and dentistry. The results revealed that the particles were able to protect the curcumin against degradation and eliminate some microorganism species at nanomolar concentrations.
\end{abstract}

Uniterms: Curcumin/study. Nanoparticles/evaluation. PLGA. Antimicrobial photodynamic therapy (aPDT).

\section{INTRODUTION}

Antimicrobial photodynamic therapy (aPDT) is a promising treatment that uses photosensitizers and visible light sources with matching resonant wavelengths. Upon irradiation, photosensitizers can initiate photochemical Type-I, Type-II, or Type-I-Type-II combination reactions. In Type-I reactions, the activated photosensitizer reacts with a substrate molecule by transferring either an electron or a hydrogen to an oxygen or another adjacent molecule to form a radical anion or cation, respectively. These radicals are likely to react with molecular oxygen to produce reactive oxygen species (ROS). These species are highly reactive and able to oxidize proteins, nucleic acids and unsaturated lipids (Huang et al., 2009). These

\footnotetext{
*Correspondence: M. V. L. Ferreira. Departamento de Engenharia Mecânica - DEMEC/ UFMG. Av. Antônio Carlos, 6627, 31270-901 - Belo Horizonte MG, Brazil. Phone: +55 +31 3409 6677. E-mail address: mvlucas@uol.com.br
}

reaction products are even more powerful oxidizing agents that may cause considerable cellular damage. In Type-II reactions, an energy transfer that occurs in the ground state of molecular oxygen leads to the production of singlet oxygens that are capable of reacting with cellular components to elicit membrane permeability, irreversible damage and cell death (Konan, Gurny, Allémann, 2002; Zeina et al., 2001; Smijs et al., 2007; Giroldo et al., 2009). There are multiple cellular mechanisms that control the levels of oxidant species, e.g., enzymes, such as superoxide dismutase, catalase, and peroxidase, and a number of secondary scavengers that reduce oxidized biomolecules. However, in robust oxidative stress conditions such as those that occur during aPDT, these cytoprotective mechanisms may be insufficient, and significant damage to the cellular constituents may occur (Szokalska et al., 2009).

Nanoparticles (NPs) are drug delivery systems that have diameters of $1 \mu \mathrm{m}$ or less (Szokalska et al., 2009). 
Photosensitizers encapsulated in polymeric nanospheres have shown excellent results in aPDT (Bechet et al., 2008). Several studies have reported that the encapsulation of photosensitizers in polymeric nanoparticles of poly(lactic-co-glycolic) acid (PLGA) increases the efficiency of photosensitizers in reducing the viability of cancer cells. PLGA is a biomaterial, biodegradable with good biocompatibility and stability, developed in the 1970s and approved by the United States Food and Drug Administration (FDA) for drug delivery (Shi et al., 2013). Ricci-Junior and Marchetti (2006) demonstrated that zinc phthalocyanine is more efficient in reducing the viability of lymphoid lineage P388D1 neoplastic cells. Pagonis and coworkers (2010) and Klepac-Ceraj and coworkers (2011) evaluated the effectiveness of methylene blue (MB, a photosensitizer with well-defined properties) in PLGA nanoparticles against suspensions and biofilms of bacteria in dental plaque with promising results.

Curcumin is a compound isolated from Curcuma longa $L$. that has been used for centuries as a medicine, dietary pigment, and spice. This drug has a variety of traditional pharmaceutical applications, including the treatment of liver diseases, wounds, and inflamed joints, as well as blood purification and microbial effects (Aggarwal et al., 2007). Curcumin exerts potent phototoxic effects in micromolar amounts and has a rather broad absorption peak in the $300-500 \mathrm{~nm}$ range (the maximum is approximately $430 \mathrm{~nm}$ ). Therefore, curcumin has potential as a photosensitizer for the treatment of localized superficial infections in the mouth or on the skin (Haukvik et al., 2010). Additionally, curcumin has economic advantages that include low cost, simple manipulation, and high effectiveness (Araújo et al., 2014). However, the clinical application of curcumin has been hindered by its poor aqueous solubility, fast hydrolytic degradation at physiological $\mathrm{pH}$ values, and presystemic metabolism by the action of colonic enzymes; the combination of these factors results in a low bioavailability of orally administered curcumin (Anand et al., 2007). Several attempts to improve the aqueous solubility (while avoiding the use of DMSO as a solubility enhancer) and stability of curcumin have been made: one way is to encapsulate the drug into polymeric nanocarriers, as PLGA nanoparticles, cyclodextrins, and surfactants (e.g., TX100, PPP, PEG400, and STC), or in solutions containing alginate or gelatin (Haukvik et al., 2009; Tonnesen, 2002; Tonnesen, Masson, Loftsson, 2002; Tonnesen, 2006).

The present work aimed to prepare, investigate the characteristics and improve the photodynamic activity of PLGA-based nanoparticles loaded with curcumin for use in aPDT therapy.

\section{MATERIAL AND METHODS}

\section{Nanoparticle construction and characterization}

The nanoparticles (NPs) were prepared with the emulsification and solvent evaporation method, and because curcumin is an insoluble drug, the oil-in-water $(\mathrm{o} / \mathrm{w})$ method was used according to previously detailed procedures (Li, Rouaud, Poncelet, 2008). Briefly, curcumin $(15 \mathrm{mg})$ and PLGA $(150 \mathrm{mg})$ were dissolved in dichloromethane (DCM) $(3.76 \mathrm{~mL})$. The organic phase was emulsified in $12 \mathrm{~mL}$ of an aqueous solution of Sodium docecyl sulfate (SDS) $(3 \%, \mathrm{w} / \mathrm{w})$ using magnetic stirring at room temperature while being protected from light. After 1 hour, the emulsion was mixed by sonication on ice with ultrasonic probe in the discontinuous mode for 3 minutes and 30 seconds to obtain the nanoparticles. After emulsification, the water-in-oil-in water emulsion was magnetically stirred for 24 hours to evaporate the organic solvent. The NPs were obtained on supernatant by centrifugation at $1500 \mathrm{~g}$ for 15 minutes. Empty PLGA NPs were prepared without the addition of curcumin using the same procedure. The NPs was cooled to $-20^{\circ} \mathrm{C}$ and freeze-dried. The solutions used in the biological assays were prepared from freeze-dried NPs dispersed in distilled water that were diluted to obtain stock solutions with concentrations of $50 \mu \mathrm{M}$ of curcumin. These solutions were diluted to $10 \mu \mathrm{M}$ of curcumin immediately before use.

The freeze-dried curcumin sample, blank nanoparticles and curcumin-loaded nanoparticles were analyzed by infrared absorption spectrometry with attenuated total reflectance (ATR-FTIR) on a FTIR Spectrometer Spectrum One (PerkinElmer, Inc., MA, USA). Scanning electron micrographs of the PLGA NPs, were obtained for the morphological characterization of the systems with an electron microscope (JEOL, model JSM-6360 LV) operated at $10 \mathrm{kV}$ in a low vacuum.

The diameters of the nanoparticles and the polydispersity index (PI) were determined with dynamic light scattering on a Zetasizer 3000 MHS (Malvern, England). The PI is an estimation of the size variability of the particles in relative to their average size. The analysis was performed in the suspension containing the nanoparticles to avoid the possible formation of aggregates that may occur during the drying stage.

The encapsulation efficiency (EE) was determined using the colloidal dispersion of NPs in distilled water. Briefly, the dispersion was centrifuged at 17,200 $\mathrm{g}$ at $4{ }^{\circ} \mathrm{C}$ for 15 minutes to remove the free curcumin. The nanoparticles in the sediments were collected and 
dissolved in DCM to its complete dissolution. The curcumin was then quantified on a spectrophotometer at $420 \mathrm{~nm}$ via comparison with a previously constructed analytical curve. The entrapment efficiency (\%) was estimated by comparing the amount of curcumin extracted from the nanoparticles with the initial amount used for the nanoparticle preparation.

\section{Biological assays}

Candida albicans (ATCC 18804), Cryptococcus neoformans (ATCC 90112), and Staphylococcus epidermidis (ATCC 12228) were used in NP microbiological assays. All the reference strains have been kept in ultra-low temperature freezers at $-80{ }^{\circ} \mathrm{C}$. S. epidermidis was cultured on Tryptic Soy Agar (TSA) (Difco) and C. albicans and C. neoformans were grown on Sabouraud Agar (Sb) (SDA; Difco Laboratories, Sparks, $\mathrm{MD})$ at $37^{\circ} \mathrm{C}$, in aerobic conditions, for 24 hours.

The aPDT assays were performed according to the methods of Soares et al. (2009) with modifications. Standardized microbial suspensions (McFarland $10^{8}$ cells $/ \mathrm{mL}$ ) were employed to obtain a final inoculum of $10^{2}$ cells $/ \mathrm{mL}$ by serial dilution. The curcumin-loaded NPs were used as a photosensitizer at $10 \mu \mathrm{M}$ and different irradiation times were tested for each microorganism. The pre-irradiation time was 5 minutes. The light source was a blue monochromatic light-emitting diode (LED; Fisioled, MMOptics, São Paulo, Brazil) with an energy density of $36 \mathrm{~J} / \mathrm{cm}^{2}$, a power of $100 \mathrm{~mW}$, an intensity of $200 \mathrm{mV} /$ $\mathrm{cm}^{2}$, and a light spot of $1.5 \mathrm{~cm}^{2}$ in an active medium containing indium, gallium, aluminum and phosphorus. The experiments were conducted in 96-well microliter plates (flat bottom) in the absence of external light with the exception of the LED. The following irradiation times were used: 8 minutes for $C$. albicans, 1 minute for C. neoformans, and 4 minutes for $S$. epidermidis. The following controls were employed for each assay: 1) untreated control (microbial strain without irradiation) to follow the microbial grow without any interference; 2 ) empty NPs control (microbial strain + empty NPs without irradiation) to test the formulation toxicity; 3 ) empty NP control that was also tested with light (microbial strain + empty NPs with irradiation), to evaluated interactions between NP and light; 4) NP loaded with curcumin control (microbial strains + loaded NPs without irradiation) to test the toxicity of formulation with curcumin. Previous experiments with microorganisms exposed only to light source has the same cellular growth as untreated group (data no shown). To evaluate cell viability following the aPDT treatment, aliquots of treated suspensions were plated on TSA or Sb media and incubated at 37 ${ }^{\circ} \mathrm{C}$, in aerobic conditions, for 24 hours. At the end of the incubation period, visual counting of colony-forming units (CFU) was performed and the results were expressed in $\mathrm{CFU} / \mathrm{mL}$.

\section{RESULTS}

\section{Nanoparticle construction and characterization}

Nanoparticulate drug delivery systems offer numerous advantages over the conventional dosage forms. These advantages include improved efficacy, reduced toxicity and improved patient compliance (Fuente et al., 2010). In the present work, nanoparticles carrier of curcumin for use in aPDT were prepared, characterized and evaluated. The method of preparation was very simple and involved mild conditions.

The ATR-FTIR spectra of the nanoparticles produced in this context are represented in Figure 1. The characteristic absorption bands of PLGA were preserved in the curcumin-loaded formulation without considerable shifts, which suggests no obvious reaction between the polymer and the curcumin.

The electron micrographs (Figure 2) revealed clusters of particles in the micrometer and nanometer scales. It can be inferred that this agglomeration occurred during the drying of the analyzed material. This fact made the determination of the particle size in this technique difficult.

Based on the dynamic light scattering technique, the PLGA particles carrying curcumin had an average size of $139.5 \pm 1.8 \mathrm{~nm}$ and 0.3 of PI. The PI is a measure of dispersion homogeneity and ranges from 0 to 1 . Values close to zero indicate a homogeneous dispersion while those greater than 0.3 indicate high heterogeneity. (Zhang, Kosaraju, 2007). Size and size distribution of nanoparticles depend largely on concentration, molecular weight, and conditions of mixing.

The concentration of curcumin in the final formulation was $0.17 \pm 0.05 \mathrm{mg} / \mathrm{mL}$ to the PLGA NPs. This result indicates that $14 \%$ of the drug initially used in the formulation was incorporated in the NPs.

\section{Biological assays}

The biological assays began with the assessment of the activity of PLGA NPs against fungi and bacteria that were selected for their importance in dentistry and dermatology. 


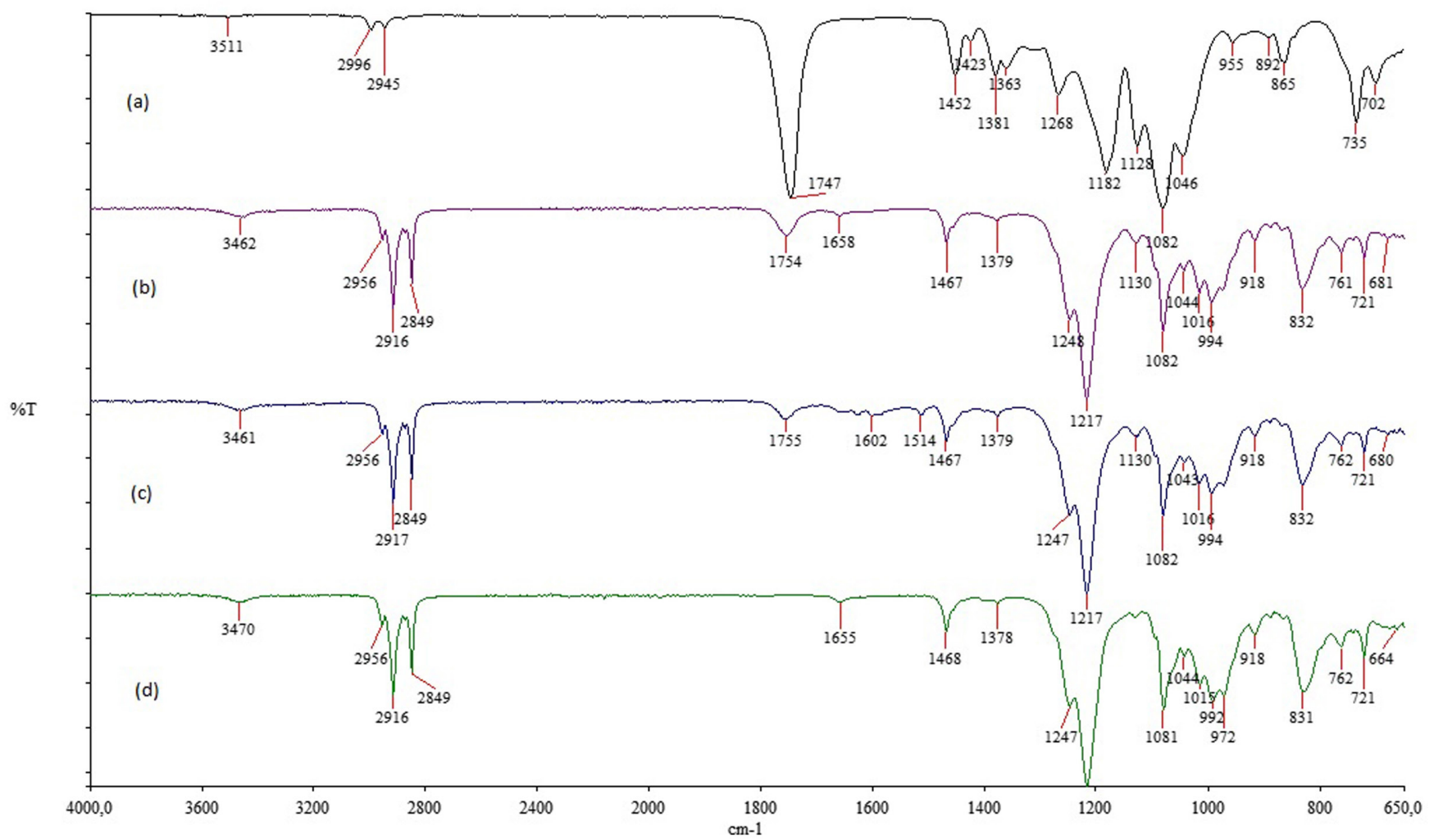

FIGURE 1 - ATR-FTIR spectra of the PLGA (a), blank nanoparticles (b) curcumin-loaded nanoparticles (c) and SDS (d).
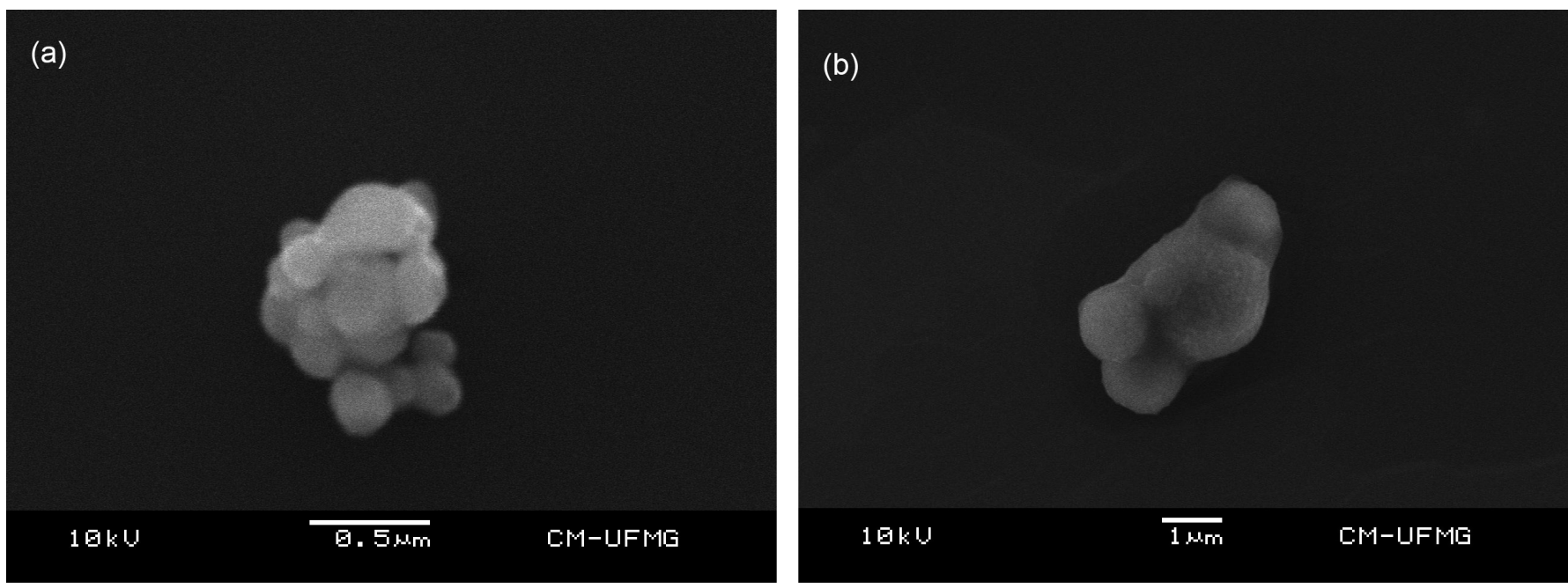

FIGURE 2 - Electron micrographs of the PLGA/curcumin-loaded nanoparticles at 10,000 (a) and 100,000 (b) magnification.

\section{Candida albicans}

The results obtained indicated that there were no important differences between the number of viable cells exhibited by the control groups (Figure 3), indicating that in the absence of light, PLGA and curcumin-loaded PLGA did not reduce the viability of the fungus. However, in the groups that were treated with light in association with NPs, a fungicidal effect was observed, i.e., a reduction in the growth of $C$. albicans was observed. The
PLGA+curcumin+light combination was more efficient to reduce the microbial growth (97\%) than PLGA+light combination $(71 \%)$.

\section{Cryptococcus neoformans}

The results of the aPDT treatments using particles of curcumin against $C$. neoformans are shown in Figure 4. In general the results observed for C. neoformans were similar to those obtained for $C$. albicans. PLGA 


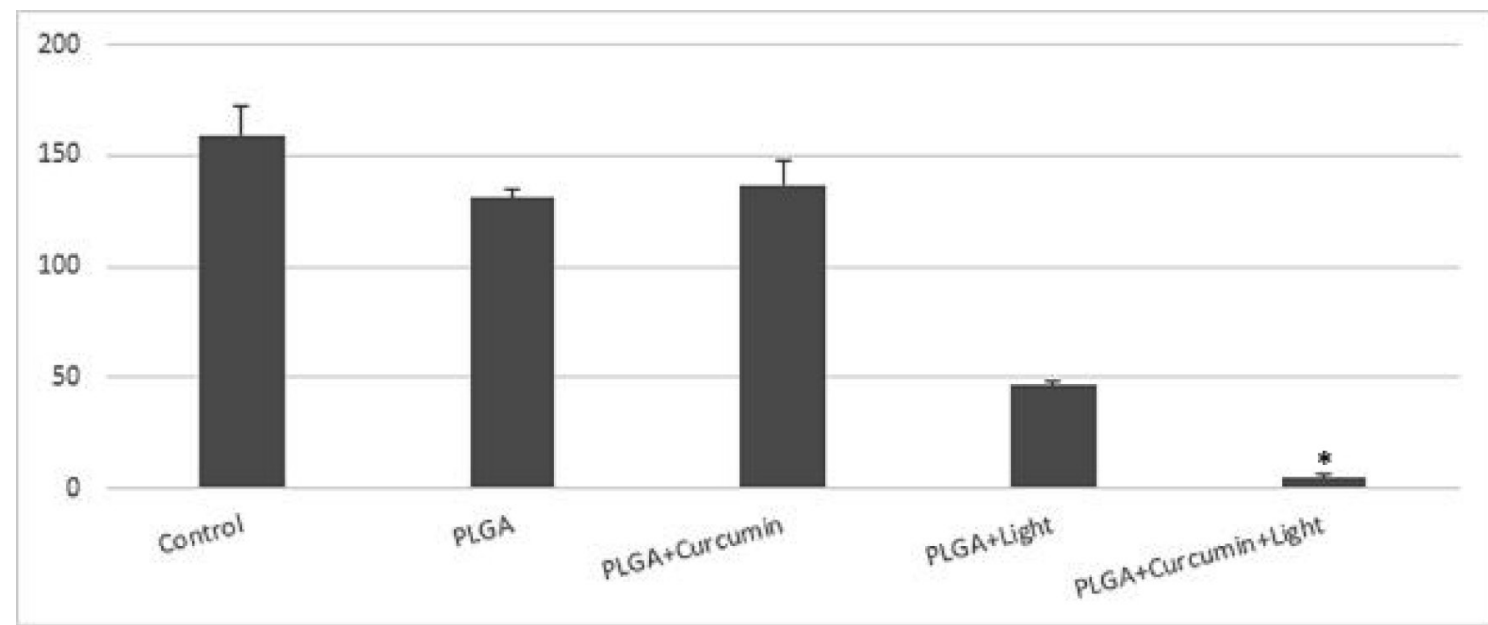

FIGURE 3 - Effects of antimicrobial photodynamic therapy (aPDT) with PLGA NPs against Candida albicans ATCC 18804. The viabilities for each of the following treatment groups are shown: control (no NPs and no light), PLGA (empty NPs without light), PLGA+curcumin (NPs without light), PLGA+light (empty NPs with light), and PLGA+curcumin+light (aPDT). C. albicans was cultivated in $\mathrm{Sb}$ agar (control). The treatments were performed with an exposure time of 8 minutes.

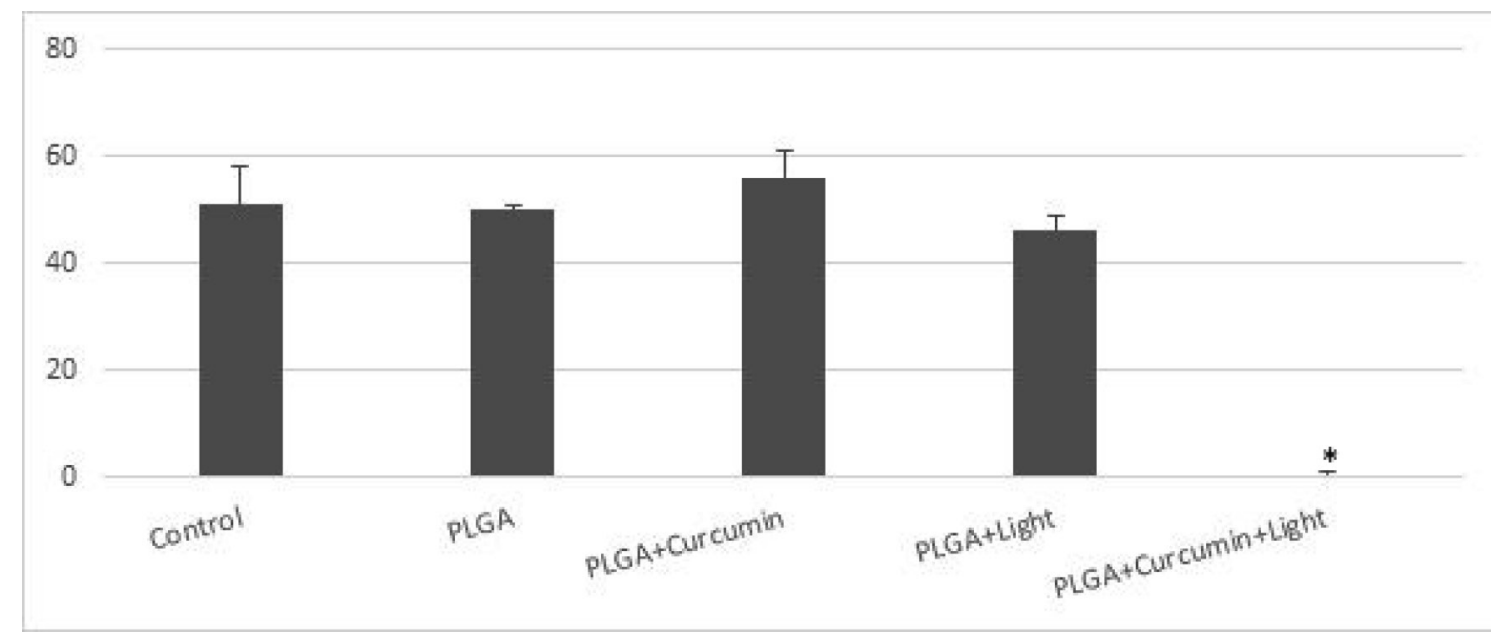

FIGURE 4 - Effect of antimicrobial photodynamic therapy (aPDT) with PLGA NPs against Criptococcus neoformans ATCC 90112 for each of the following treatment groups: control (no NPs and no light), PLGA (empty NPs without light), PLGA+curcumin (NPs without light), PLGA+light (empty NPs with light), and PLGA+curcumin+light (aPDT).C. neoformans was cultivated in Sb agar (control). The treatments were performed at the exposure time of 1 minute.

and curcumin-loaded PLGA did not reduce the viability of the fungus in the absence of light but the PLGA+curcumin+light combination was able to inhibit $99 \%$ of the microbial growth. On the other hand, no important reduction of $C$. neoformans viability was induced by PLGA+light.

\section{Staphylococcus epidermidis}

The results revealed that aPDT completely inhibited $S$. epidermidis growth (Figure 5). However, a small reduction in bacterial viability due to empty particles in the presence of light was observed (38\%).

\section{DISCUSSION}

Curcumin is a naturally occurring drug of the polyphenol superfamily, which exhibits anti-oxidant, anti-inflammatory and anticancer properties (Vallianou et al., 2015). However, the physicochemical characteristics of curcumin, i.e., its poorly solubility in aqueous solution and high photosensitivity, prevent its widespread use. To improve its potential utility in aPDT, we attempted to develop a curcumin-encapsulated PLGA nanoparticle formulation via the emulsification and solvent evaporation method. We characterized these 


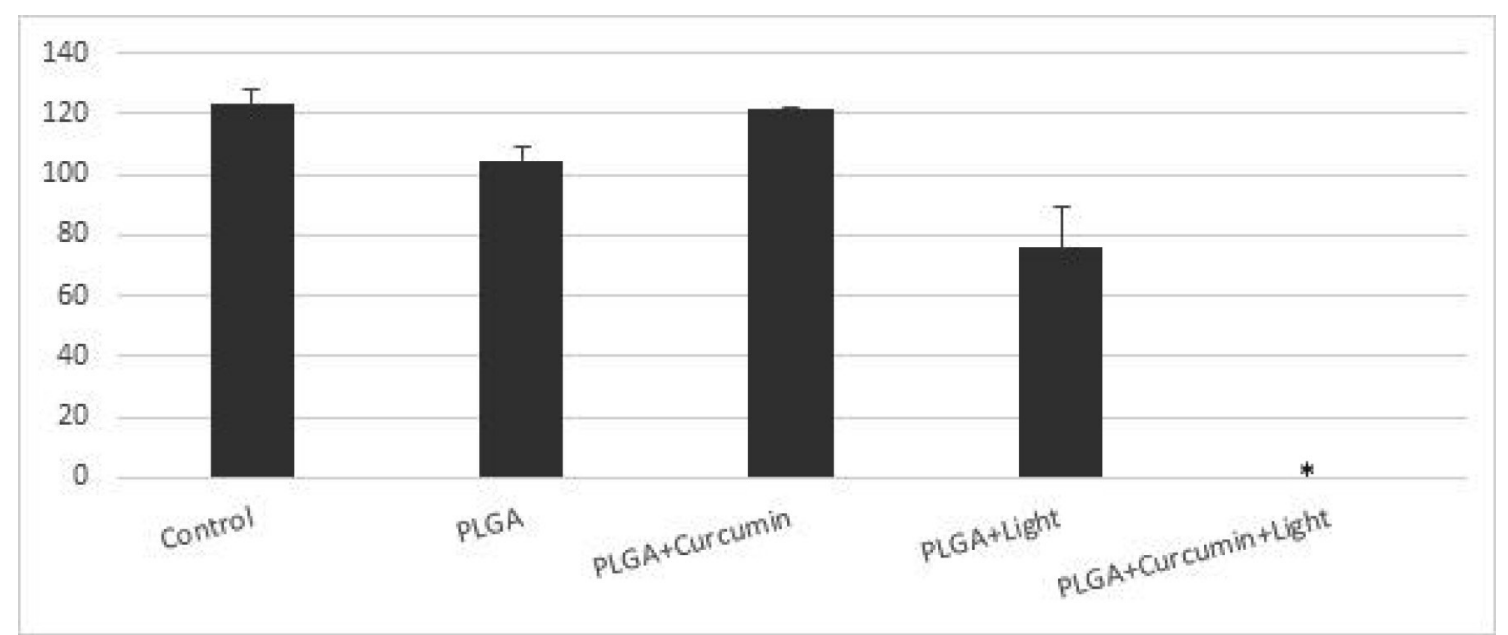

FIGURE 5 - Effects of antimicrobial photodynamic therapy (aPDT) with PLGA NPs against Staphylococcus epidermidis ATCC 12228 in each of the following treatment groups: control (no NPs and no light), PLGA (empty NPs without light), PLGA+curcumin (NPs without light), PLGA+light (empty NPs with light), and PLGA+curcumin+light (aPDT). S. epidermidis was cultivated in TSA (control). The treatments were performed at the exposure time of 4 minutes.

particles and tested their effects against some clinically relevant microorganisms.

The choice to conjugate the photosensitizer in polymeric nanoparticles was based on the numerous benefits offered by this system, such as the ability to improve the delivery of water-insoluble drugs, the potential to control drug release, the extensive range of polymers that may be used, the different methods by which the particles may be produced, and the potential to protect the compounds from inactivation and to enhance their pharmacological activities (NguyenNgoc, Raymond, 2015; Teixeira et al., 2005; Fonseca, Simões, Gaspar, 2002; Lowe, Temple, 1994). PLGA was selected because it has been used as a nanocarrier for many bioactive molecules (e.g., drugs, peptides, proteins, DNA, and oligonucleotides) due to its low toxicity, good biocompatibility, and FDA approval status (Lü et al., 2009). Drug release from PLGA nanoparticles is a complex process that involves diffusion followed by degradation, the molecular weight ratio of the PLGA copolymer, protected layer stability, and the physicochemical properties of the drug. The poor drug loading may have been due to the minimal swelling ability of the PLGA macromolecular chains in aqueous media for the entrapment of curcumin (Yallapu et al., 2010).

The microencapsulation technique of solvent evaporation has been widely applied in the pharmaceutical industry to achieve the controlled release of the drug. The obtained polymer microspheres with the drug trapped inside can degrade and release the encapsulated drug slowly with a specific release profile (Li, Rouaud, Poncelet, 2008). Grabovac and Bernkop-Schnurch (2007) used curcumin and PLGA also with the emulsion solvent evaporation method to obtain particles with surface modifications. There are different methods for the use of microencapsulation with the solvent evaporation technique. The choice of the method for producing efficient drug encapsulation depends on the hydrophilicity or the hydrophobicity of the drug. For insoluble or poorly water-soluble drugs, such as curcumin, the oil-in-water $(\mathrm{o} / \mathrm{w})$ method is frequently used (Li, Rouaud, Poncelet, 2008). Some authors who have worked with PLGA and curcumin particles have also used different methodologies, such as solvent evaporation diffusion (Shaikh et al., 2009), nano-precipitation (Anand et al., 2010; Yallapu et al., 2010), double-emulsion solvent evaporation (Koppolu et al., 2009; Mukerjee, Vishwanatha, 2009) and extrusion through $0.2 \mu \mathrm{m}$ filters (Sou et al., 2008). Mukerjee and Vishwanatha (2009) and Yallapu et al. (2010) used a polyvinyl alcohol solution (PVA) as a particle stabilizer and obtained $90 \%$ and $50 \%$ encapsulation efficiencies, respectively. With the aim of developing a simpler, more cost-effective formulation, we did not use adjuvants in the encapsulation process.

The preliminary results obtained in biological assays revealed that the proposed formulation elicited complete elimination of $S$. epidermidis viability and significant viability reduction for the studied fungi species following the use of nanomolar concentrations of curcumin. The treatment of infectious diseases is not an easy task. In fact the procedure is often complex and many times requires the use of high doses and/or a combination of antibiotics. Moreover the outcome is not always satisfactory (Nucci, Marr, 2005; Hof, 2008; Miceli, Díaz, Lee, 2011). 
Antimicrobial resistance has often been observed in different microbial species and has become a worldwide problem (Miceli, Díaz, Lee, 2011). Interestingly, in the search for new therapeutic alternatives, in vitro studies have shown that aPDT could be an effective method for the treatment of candidiasis based on the observed reductions in the viability and adhesion of Candida spp. including those isolates that are resistant to fluconazole (Soares et al., 2009). Another in vitro study showed that aPDT may be very effective in the treatment of cryptococcosis because it substantially reduces the viability of Cryptococcus gatii, including samples that exhibited resistance to antifungals. These results further validate the use of variablesensitivity aPDT (Soares et al., 2011). The results obtained in the present study, albeit preliminary, suggest a new path because there are still no reports of resistance to aPDT.

One interesting result is the fact that the curcumin, which was initially verified to be unstable and very susceptible to the presence of light (Megalathan et al., 2016), was stabilized by interactions with PLGA particles that exhibited no in vitro toxicity. The suspension prepared for this study kept its biological activity for a storage period of more than 30 days at $-20^{\circ} \mathrm{C}$.

\section{CONCLUSION}

Polymeric nanoparticles based on PLGA have been developed and characterized. These nanoparticles exhibited potential for use as drug carriers and the substantial advantage of maintaining the biological activity of curcumin and improving its solubility in water. This construction could be a promising alternative solution for use in aPDT assays against different microbiological species. Additional studies are being performed to increase the yield of the encapsulated photosensitizers, their stabilities, and their activities against other microorganisms.

\section{ACKNOWLEDGEMENTS}

The authors would like to thank FAPEMIG, CNPq and FINEP for providing financial support for this work.

\section{REFERENCES}

AGGARWAL, B.B.; SUNDARAM, C.; MALANI, N.; ICHIKAWA, H. Curcumin: the Indian solid gold. Adv. Exp. Med. Biol., v.595, p.1-75, 2007.
ANAND, P.; KUNNUMAKKARA, A.B.; NEWMAN, R.A.; AGGARWAL, B.B. Bioavailability of curcumin: problems and promises. Mol. Pharm., v.4, n.6, p.807-818, 2007.

ANAND, P.; NAIR, H.B.; SUNG, B.; KUNNUMAKKARA, A.B.; YADAV, V.R.; TEKMAL, R.R.; AGGARWAL, B.B. Design of curcumin-loaded PLGA nanoparticles formulation with enhanced cellular uptake, and increased bioactivity in vitro and superior bioavailability in vivo. Biochem. Pharmacol., v.79, n.3, p.330-338, 2010.

ARAÚJO, N.C.; FONTANA, C.R.; BAGNATO, V.S.; GERBI, M.E. Photodynamic antimicrobial therapy of curcumin in biofilms and carious dentine. Lasers Med. Sci., v.29, n.2, p.629-635, 2014.

BECHET, D.; COULEAUD, P.; FROCHOT, C.; VIRIOT, M.L.; GUILLEMIN, F.; BARBERI-HEYOB, M. Nanoparticles as vehicles for delivery of photodynamic therapy agents. Trends Biotechnol., v.26, n.11, p.612-621, 2008.

FONSECA, C.; SIMÕES, S.; GASPAR, R. Paclitaxel-loaded PLGA nanoparticles: preparation, physicochemical characterization and in vitro anti-tumoral activity. $J$. Control. Release, v.83, n.2, p.273-286, 2002.

FUENTE, M.; RAVIÑA, M.; PAOLICELLI, P.; SANCHEZ, A.; SEIJO, B.; ALONSO, M.J. Chitosan-based nanostructures: a delivery platform for ocular therapeutics. Adv. Drug Deliv. Rev., v.62, n.1, p.100-117, 2010.

GIROLDO, L.M.; FELIPE, M.P.; DE OLIVEIRA, M.A.; MUNIN, E.; ALVES, L.P.; COSTA, M.S. Photodynamic antimicrobial chemotherapy (PACT) with methylene blue increases membrane permeability in Candida albicans. Lasers Med. Sci., v.24, n.1, p.109-112, 2009.

GRABOVAC, V.; BERNKOP-SCHNÜRCH, A. Development and in vitro evaluation of surface modified poly(lactide-coglycolide) nanoparticles with chitosan-4-thiobutylamidine. Drug Dev. Ind. Pharm., v.33, n.7, p.767-774, 2007.

HAUKVIK, T.; BRUZELL, E.; KRISTENSEN, S.; TONNESEN, H.H. Photokilling of bacteria by curcumin in different aqueous preparations. Studies on curcumin and curcuminoids XXXVII. Pharmazie, v.64, n.10, p.666-673, 2009. 
HAUKVIK, T.; BRUZELL, E.; KRISTENSEN, S.; TONNESEN, H.H. Photokilling of bacteria by curcumin in selected polyethylene glycol 400 (PEG 400) preparations. Studies on curcumin and curcuminoids, XLI. Pharmazie, v.65, n.8, p.600-606, 2010.

HOF, H. Will resistance in fungi emerge on a scale similar to that seen in bacteria? Eur. J. Clin. Microbiol. Infect. Dis., v.27, n.5, p.327-334, 2008.

HUANG, Y.Y.; CHEN, A.C.H.; CARROLL J.D.; HAMBLIN, M.R. Biphasic dose response in low level light therapy. Dose Response, v.7, n.4, p.358-383, 2009.

KLEPAC-CERAJ, V.; PATEL, N.; SONG, X.; HOLEWA, C.; PATEL, C.; KENT, R.; AMIJI, M.M.; SOUKOS, N.S. Photodynamic effects of methylene blue- loaded polymeric nanoparticles on dental plaque bacteria. Lasers Surg. Med., v.43, n.7, p.600-606, 2011.

KONAN, Y.N.; GURNY, R.; ALLÉMANN, E. State of the art in the delivery of photosensitizers for photodynamic therapy. J. Photochem. Photobiol. B., v.66, n.2, p.89-106, 2002.

KOPPOLU, B.P.; RAHIMI, M.; NATTAMA, S.P.; WADAJKAR, A.; NGUYEN, K. Development of multiple-layer polymeric particles for targeted and controlled drug delivery. Nanomedicine, v.6, n.2, p.355-361, 2009.

LI, M.; ROUAUD, O.; PONCELET, D. Microencapsulation by solvent evaporation: state of the art for process engineering approaches. Int. J. Pharm., v.363, n.1-2, p.26-39, 2008.

LOWE, P.J.; TEMPLE, C.S. Calcitonin and insulin in isobutylc yanoacrylatenanocapsules: protection against proteases and effect on intestinal absorption in rats. J. Pharm. Pharmacol., v.46, n.7, p.547-552, 1994.

LÜ, J.M.; WANG, X.; MARIN-MULLER, C.; WANG, H.; LIN, P.H.; YAO, Q.; CHEN, C. Current advances in research and clinical applications of PLGA-based nanotechnology. Expert Rev. Mol. Diagn., v.9, n.4, p.325-341, 2009.

MEGALATHAN, A.; KUMARAGE, S.; DILHARI, A.; WEERASEKERA, M.M.; SAMARASINGHE, S.; KOTTEGODA, N. Natural curcuminoids encapsulated in layered double hydroxides: a novel antimicrobial nanohybrid. Chem. Cent. J., v.10, p. 35, 2016.
MICELI, M.H.; DÍAZ, J.A.; LEE, S.A. Emerging opportunistic yeast infections. Lancet Infect. Dis., v.11, n.2, p.342-351, 2011.

MUKERJEE, A.; VISHWANATHA, J.K. Formulation, characterization and evaluation of curcumin-loaded PLGA nanospheres for cancer therapy. Anticancer Res., v.29, n.10, p.3867-3875, 2009.

NGUYEN-NGOC, T.; RAYMOND, E. Reinvention of chemotherapy: drug conjugates and nanoparticles. Curr. Opin. Oncol., v.27, n.3, p.232-242, 2015.

NUCCI, M.; MARR, K. Emerging fungal diseases. Clin. Infect. Dis., v.41, n.4, p.521-524, 2005.

PAGONIS, T.C.; CHEN, J.; FONTANA, C.R.; DEVALAPALLY, H.; RUGGIERO, K.; SONG, X.; FOSCHI, F.; DUNHAM, J.; SKOBE, Z.; YAMAZAKI, H.; KENT, R.; TANNER, A.C.; AMIJI, M.M.; SOUKOS, N.S. Nanoparticle-based endodontic antimicrobial photodynamic therapy. J. Endod., v.36, n.2, p.322-328, 2010.

RICCI-JUNIOR, J.; MARCHETTI, M. Zinc(II) phthalocyanine loaded PLGA nanoparticles for photodynamic therapy use. Int. J. Pharm., v.310, n.1-2, p.187-195, 2006.

SHAIKH, J.; ANKOLA, D.D.; BENIWAL, V.; SINGH, D.; KUMAR, M.N. Nanoparticle encapsulation improves oral bioavailability of curcumin by at least 9-fold when compared to curcumin administered with piperine as absorption enhancer. Eur. J. Pharm. Sci., v.37, n.3-4, p.223230, 2009.

SHI, L.; WANG, X.; ZHAO, F.; LUAN, H.; TU, Q.; HUANG, Z.; WANG, H.; WANG, H. In vitro evaluation of 5-aminolevulinic acid (ALA) loaded PLGA nanoparticles. Int. J. Nanomed., v.8, n.1, p.2669-2676, 2013.

SMIJS, T.G.M.; BOUWSTRA, J.A.; SCHUITMAKER, H.J.; TALEBI, M.; PAVEL, S. A novel ex vivo skin model to study the susceptibility of the dermatophyte Trichophyton rubrum to photodynamic treatment in different growth phases. $J$. Antimicrob. Chemother., v.59, n.3, p.433-440, 2007.

SOARES, B.M.; DA SILVA, D.L.; SOUSA, G.R.; AMORIM, J.C.; DE RESENDE, M.A.; PINOTTI, M.; CISALPINO, P.S. In vitro photodynamic inactivation of Candida $s p p$. growth and adhesion to buccal epithelial cells. $J$. Photochem. Photobiol. B., v.94, n.1, p.65-70, 2009. 
SOARES, B.M.; ALVES, O.A.; FERREIRA, M.V.; AMORIM, J.C.; SOUSA, G.R.; SILVEIRA, L.B.; PRATES, R.A.; AVILA, T.V.; BALTAZAR, L.M.; SOUZA, D.G.; SANTOS, D.A.; MODOLO, L.V.; CISALPINO, P.S.; PINOTTI, M. Cryptococcus gattii: in vitro susceptibility to photodynamic inactivation. Photochem. Photobiol., v.87, n.2, p.357-364, 2011.

SOU, K.; INENAGA, S.; TAKEOKA, S.; TSUCHIDA, E. Loading of curcumin into macrophages using lipid-based nanoparticles. Int. J. Pharm., v.352, n.1-2, p.287-293, 2008.

SZOKALSKA, A.; MAKOWSKI, M.; NOWIS, D.; WILCZYNSKI, G.M.; KUJAWA, M.; WÓJCIK, C.; MLYNARCZUK-BIALY, I.; SALWA, P.; BIL, J.; JANOWSKA, S.; AGOSTINIS, P.; VERFAILLIE, T.; BUGAJSKI, M.; GIETKA, J.; ISSAT, T.; GLODKOWSKA, E.; MRÓWKA, P.; STOKLOSA, T.; HAMBLIN, M.R.; MRÓZ, P.; JAKÓBISIAK, M.; GOLAB, J. Proteasome inhibition potentiates antitumor effects of photodynamic therapy in mice through induction of endoplasmic reticulum stress and unfolded protein response. Cancer Res., v.69, n.10, p.4235-4243, 2009.

TEIXEIRA, M.; ALONSO, M.J.; PINTO, M.M.; BARBOSA, C.M. Development and characterization of PLGA nanospheres and nanocapsules containing xanthone and 3-methoxyxanthone. Eur. J. Pharm. Biopharm., v.59, n.3, p.491-500, 2005.

TONNESEN, H.H. Solubility, chemical and photochemical stability of curcumin in surfactant solutions. Studies of curcumin and curcuminoids, XXVIII. Pharmazie, v.57, n.12, p.820-824, 2002.
TONNESEN, H.H. Solubility and stability of curcumin in solutions containing alginate and other viscosity modifying macromolecules. Studies of curcumin and curcuminoids. XXX. Pharmazie, v.61, n.8, p.696-700, 2006.

TONNESEN, H.H.; MASSON, M.; LOFTSSON, T. Studies of curcumin and curcuminoids. XXVII. Cyclodextrin complexation: solubility, chemical and photochemical stability. Int. J. Pharm., v.244, n.1-2, p.127-135, 2002.

VALLIANOU, N.G.; EVANGELOPOULOS, A.; SCHIZAS, N.; KAZAZIS, C. Potential anticancer properties and mechanisms of action of curcumin. Anticancer Res., v.35, n.2, p.645-651, 2015.

YALLAPU, M.M.; GUPTA, B.K.; JAGGI, M.; CHAUHAN, S.C. Fabrication of curcumin encapsulated PLGA nanoparticles for improved therapeutic effects in metastatic cancer cells. J. Colloid Interface Sci., v.351, n.1, p.19-29, 2010.

ZHANG, L.; KOSARAJU, S.L. Biopolymeric delivery system for controlled release of polyphenolic antioxidants. Eur. Polym. J., v.43, n.7, p.2956-2966, 2007.

ZEINA, B.; GREENMAN, J.; PURCELL, W.M.; DAS, B. Killing of cutaneous microbial species by photodynamic therapy. Br. J. Dermol., v.144, n.2, p.274-278, 2001.

Received for publication on $14^{\text {th }}$ March 2016 Accepted for publication on $03^{\text {rd }}$ May 2017 